\title{
The Impact of Global Economic Policy Uncertainty, Geopolitical Risk and Oil Price on Stock Market: Evidence From Asean Countries
}

\section{Norashikin Adam, Norzahidah Yacob}

To Link this Article: http://dx.doi.org/10.6007/IJARAFMS/v12-i1/11674 DOI:10.6007/IJARAFMS /v12-i1/11674

Received: 11 November 2021, Revised: 16 December 2021, Accepted: 29 December 2021

Published Online: 15 January 2022

In-Text Citation: (Adam \& Yacob, 2022)

To Cite this Article: Adam, N., \& Yacob, N. (2022). The Impact of Global Economic Policy Uncertainty, Geopolitical Risk and Oil Price on Stock Market: Evidence From Asean Countries. International Journal of Academic Research in Accounting Finance and Management Sciences, 12(1), 28-46.

Copyright: @ 2022 The Author(s)

Published by Human Resource Management Academic Research Society (www.hrmars.com)

This article is published under the Creative Commons Attribution (CC BY 4.0) license. Anyone may reproduce, distribute, translate and create derivative works of this article (for both commercial and non-commercial purposes), subject to full attribution to the original publication and authors. The full terms of this license may be seen at: http://creativecommons.org/licences/by/4.0/legalcode

Vol. 12, No. 1, 2022, Pg. 28 - 46

Full Terms \& Conditions of access and use can be found at http://hrmars.com/index.php/pages/detail/publication-ethics 


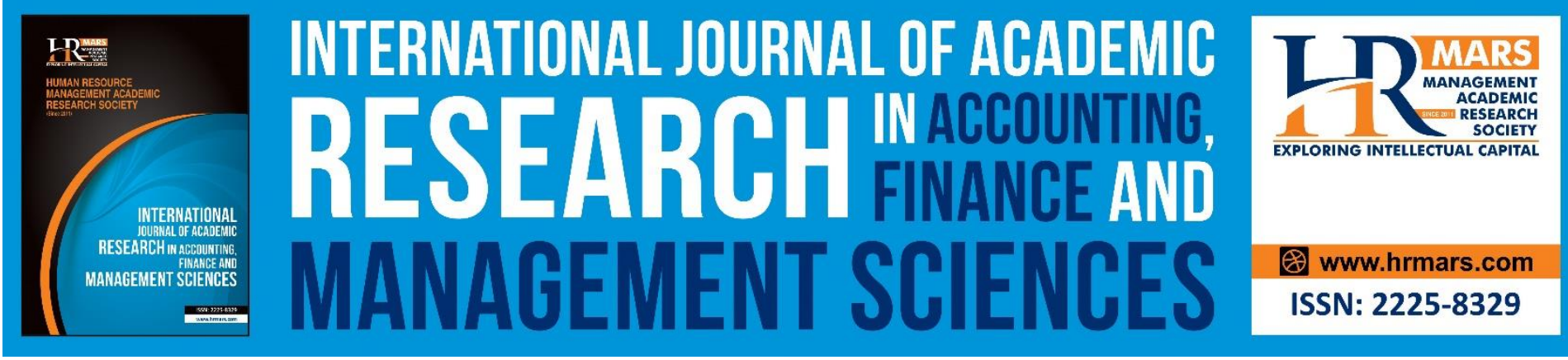

\title{
The Impact of Global Economic Policy Uncertainty, Geopolitical Risk and Oil Price on Stock Market: Evidence From Asean Countries
}

\author{
Norashikin Adam, Norzahidah Yacob \\ Faculty of Business Management, Universiti Teknologi MARA (UiTM), Malaysia.
}

\begin{abstract}
Using monthly data from January 1997 to July 2020, this study examines the impact of Global Economic Policy Uncertainty (GEPU), Geopolitical Risk (GPR), and oil price (WTI) on ASEAN stock exchanges such as the Jakarta Stock Exchange (JSE), Kuala Lumpur Composite Index $(\mathrm{KLCl})$, Philippine Stock Exchange (PSI), Stock Exchange of Thailand (SET), and Vietnam Stock Index (VNI). We use a two-stage Markov switching model to model market returns as a timevarying transition probability Markovian process. The findings reveal some fascinating new information, such as the fact that global policy uncertainty has a strong negative impact on the bulk of ASEAN stock returns during periods of high volatility. Another finding shows that, contrary to assumptions, geopolitical concerns had no effect across all samples. We also discovered that, in both the low and high volatility regimes, oil price changes have a considerable impact on all ASEAN stock markets.
\end{abstract}

Keywords: ASEAN Stock Market, Global Economic Policy Uncertainty, Geopolitical Risk, Oil Price, Markov Switching Model.

\section{Introduction}

Most Southeast Asian stock markets recovered back some ground lost in previous trends in May 2020, as certain governments and U.S. states eased coronavirus restrictions in stages, bolstering optimism of an economic revival. A stronger finish on Wall Street overnight boosted the mood, as a surge in technology companies overshadowed concerns about simmering US-China tensions over the origin of the coronavirus. The statements of the progressive reopening of countries and regions heavily struck by the COVID-19 outbreak seemed to reassure investors. For example, after statistics showed annual inflation fell to a five-month low in April, Philippine stocks soared, leading advances in the region. According to economists, the central bank will have more room to decrease interest rates and reduce banks' reserve requirement ratio to stimulate growth due to the declining trend in inflation. Meanwhile, the Straits Times Index in Singapore and Malaysia rose, boosted by financials and energy-related sectors. ASEAN stocks, on the other hand, ended mixed due to increased coronavirus infections and geopolitical tensions. Geopolitical risks are seen as key influencers of investment decisions and stock market dynamics by entrepreneurs, market players, and central bank authorities (Caldara and lacoviello, 2018). In a Gallup poll of over 1,000 investors 
MANAGEMENT SCIENCES

Vol. 12, No. 1, 2022, E-ISSN: 2225-8329 @ 2022 HRMARS

conducted in 2017, 75\% of those polled indicated concern about the economic impact of various military and diplomatic crises throughout the world, placing geopolitical risk ahead of political and economic uncertainty. Global Economic Policy Uncertainty (GEPU) is another global risk factor that has an impact on global financial market performance (Arouri et al., 2016; Baker et al., 2016). GEPU can reflect the global economy, uncertainty, and policyrelated problems as a GDP-weighted average of the national EPU indices of 16 nations. It's a good indicator of global policy uncertainty, which market investors are worried about. EPU and GEPU are gaining popularity in the literature. It has a direct impact on economic agents' employment, spending, saving, and investment decisions, as well as stock market involvement and performance (Arouri et al., 2016; Gulen and Ion, 2015). Through a reduction in the number of local and international investors, GEPU also eliminates the financing environment and the degree of economic freedom that influence stock market performance. Furthermore, the GEPU has an impact on commodity markets, such as oil prices, which in turn has an impact on stock market and economic performance (Kang et al., 2017b; Kang and Ratti, 2013; Kang et al., 2017a). Apart from GEPU and GPR, the drop in oil prices has had a significant impact on global financial markets. Two months after the outbreak of COVID-19 in Wuhan, the oil price plummeted by around $30 \%$ (20\% for West Texas Intermediate (WTI) oil) as a result of the most severe slump since the Gulf War, when Saudi authorities unexpectedly decided to offer price discounts of $\$ 6$ to $\$ 8$ to their main customers in Europe, Asia, and the United States. As a result of the oil price war and anxieties about the catastrophic news of infections and patient fatalities cases coming mainly from Italy, France, and Spain, the global stock markets have fallen precipitously. In the case of ASEAN countries, global economic uncertainty (GEPU), geopolitical risk (GPR), and the impact of oil prices on stock returns receive little attention. As a result, the goal of this study is to improve our understanding of the triple influence of global policy uncertainty, geopolitical risks, and oil prices on investment and asset pricing. This paper uses a Markov Switching Model analysis approach to evaluate the effects of GEPU, GPR, and oil price on ASEAN countries' stock market indices, based on motivating facts, stock market behaviours, and knowledge gaps. From the following views, this study presents various novelties. To begin with, most empirical research have looked at EPU in home and selected economies to see how it affects stock market performance. As a result, this study aims to fill a knowledge gap in the literature by adding new evidence and literature on the effects of GEPU, GPR, and oil price changes on stock performance. Second, the nonlinear impact of GEPU, GPR, and oil price on stock market returns is captured using a Markov regime-switching model (Hamilton, 1989). Multiple structures (equations) are used in this model to characterise time series behaviours in various regimes. This model can capture more complex dynamic patterns by allowing switching between these components. Third, this research focuses on the ASEAN stock market, which has received little attention. Furthermore, ASEAN countries would provide an intriguing viewpoint because the degree and time of lockdown varies by country, resulting in some countries, such as Malaysia and Thailand, being able to revive their economies faster than Indonesia or the Philippines. They are still dealing with a staggering number of COVID19 cases on a daily basis. As a result, our research adds to the existing literature by presenting new data on how uncertainty influences stock performance. The remainder of the paper is laid out as follows. The second section contains descriptions of the datasets as well as preliminary analyses. The study's empirical framework is depicted in Section 3. The empirical data and findings are discussed in Section 4. The concluding remarks are presented in the final section. 
MANAGEMENT SCIENCES

Vol. 12 , No. 1, 2022, E-ISSN: 2225-8329 @ 2022 HRMARS

\section{Literature Reviews}

Economic uncertainty is largely caused by governments and political processes. Major economic shocks and disruptions can also result in policy-related uncertainty. The Global Financial Crisis of 2008-09, for example, presented policymakers with enormous and complex issues. There was a tremendous deal of ambiguity about how policymakers should and would respond to the difficulties, as well as what the economic implications would be. Many theoretical studies demonstrate how uncertainty can influence investment, hiring, consumption, financing costs, asset prices, output growth, and other economic outcomes (Gilchrist et al., 2014; Pastor and Veronesi, 2013; Giavazzi and McMahon, 2012; Panousi and Papanikolaou, 2012; Fernandez-Villaverde et al., 2015). COVID-19 has a detrimental but shortterm influence on the stock markets of impacted countries, according to He et al. (2020). COVID-19 has bidirectional stock market spillover effects between Asian countries and European and American countries. COVID-19, on the other hand, does not appear to have a greater negative impact on these countries' stock markets than the worldwide average. It also adds to the body of knowledge about the pandemic's economic impact by demonstrating that COVID-19 has spillover effects on stock markets in other countries. Global risk factors like geopolitical risk, global economic policy uncertainty (GEPU), and oil price have been shown to have a substantial impact on stock performance at the aggregated stock market, industry level, and business level. (Antonakakis et al., 2013; Antonakakis et al., 2017; Caldaray and lacoviello, 2016; Kang et al., 2017a \& 2017b; Kang \& Ratti, 2013; Kang et al., 2017a \& 2017b; Kang \& Ratti, 2013; Kang et al., 2017a \& 2017b; Kang \& Ratti, 2013; Kang One of the most prominent global risk variables in global financial market performance is global economic policy uncertainty (GEPU) (Arouri et al., 2016; Baker et al., 2016). The GEPU Index is a GDPweighted average of national EPU indices for 16 nations that account for two-thirds of global output, according to (Davis, 2016). In response to the Asian Financial Crisis, the 9/11 terrorist attacks, the US-led Iraq invasion in 2003, the Global Financial Crisis in 2008-09, the European immigration crisis, and concerns about the Chinese economy in late 2015, as well as the Brexit referendum in June 2016, the GEPU Index spikes sharply. GEPU predicts future monthly volatilities for the global gold futures market in a positive and significant way (Fang et al., 2018). Interestingly, when the level of global economic policy uncertainty is taken into account, Bitcoin's hedging efficacy for both global equities and global bonds improves marginally (Fang et al., 2019). The GEPU model can also anticipate the volatility of the Chinese stock market. GEPU is positively associated to the Financials and Consumer Discretionary industries, but it is negatively related to Information Technology, Materials, Telecommunication Services, and Energy, according to the study. Unlike the varied influence of GEPU on long-run volatility, long-run correlations across industries are all positively related to GEPU (Yu et al., 2018). According to Hoque and Zaidi (2019), the effects of global economic policy uncertainty differ according on regime states, sectors, and the form of effects, with negative effects outnumbering good effects. In the high-volatility environment, global economic policy uncertainty has a greater impact on stock returns. As a result, the data support the presence of an asymmetric, nonlinear, nonmonotonic, and state-dependent link between global economic policy uncertainty and Malaysian sectoral stock returns. Furthermore, the findings of the study highlight the importance of spillover effects from global uncertainty and data surprises for forecasting GDP growth in emerging market nations (Cepni and Swanson, 2020). To my knowledge, just a few research have looked into the link between GEPU and stock market volatility. Yu and Song (2018) use a Markov-switching model to study the effects of GEPU on aggregate monthly volatility and find that GEPU can lead to 
high fluctuation and higher forecasts. Fang et al (2018a) use the GARCH-MIDAS model to investigate the GEPU's information on gold futures return variance and find that the GEPU can accurately estimate future monthly volatility in gold future markets. Li et al. (2020) investigate the impacts of directional GEPU on Chinese stock market volatility, based on the changing directions of GEPU and Chinese economic policy uncertainty (EPU). Many theoretical studies demonstrate how uncertainty can influence investment, hiring, consumption, financing costs, asset prices, output growth, and other economic outcomes. According to Tsai (2017), EPU is the most influential in China, and its contagion risk spreads to different regional markets, with the exception of Europe; EPU's impact in the United States is less than that in China. On G7 countries, Ahmad and Sharma (2018) discovered a substantial relationship between output gap and U.S. Economic Uncertainty. Furthermore, global stock market uncertainty is far more important than global bond market uncertainty (Dimic et al., 2016).

GEPU also in a specific study has significant negative effects on stock market such as GEPU affects the Malaysian stock market negatively (Hoque and Zaidi, 2020), U.S. stock index (Arouri et al., 2016), S\&P index, WTI Crude Oil, 100-oz gold bar (Bams et al., 2017). Furthermore, research have revealed that the Chinese stock market has a beneficial and considerable impact (Yang and Jiang 2016; Liu and Zhang 2015; Cristou et al., 2017). Furthermore, Mora's (2019) findings suggest that before 2010, both the GEPU and VIX indices had a considerable impact on stock market outcomes in Thailand. The impact of GEPU on stock returns after 2010 are not statistically significant. Since 1985, a count of newspaper stories covering geopolitical tensions has been used to assess the evolution and impact of geopolitical risk. The geopolitical risk (GPR) index spikes around the Gulf War, after 9/11, during the 2003 Iraq invasion, during the 2014 Russia-Ukraine crisis, and after the Paris terrorist attacks. High geopolitical risk causes a drop in real activity, weaker stock returns, and capital flow moves away from emerging nations and toward mature economies (Caldara and lacoviello, 2018). The Islamic stock market getting an asymmetric response to geopolitical shock can be because of multiple determinants related to the Islamic stock market and different Islamic stock market environments in each economy (Oad et al., 2019). Antonakakis et al. (2017) reveal that geopolitical risk triggers a negative effect, mainly on oil returns and volatility, and to a smaller degree on the covariance between the two markets. The impact of geopolitical risk is significant for oil prices. It may be related to some geopolitical events (e.g. terror attacks in oil fields) that directly affect oil production but receive limited global press coverage (Smales, 2019). According to Sharif et al (2020), they found that COVID-19 outbreak has a greater effect on the U.S. geopolitical risk and on the U.S. economic uncertainty, the oil slump had the strongest impact on the U.S. stock markets in comparison to both COVID-19, EPU and GPR and the COVID-19 pandemic also affect the oil prices, which can be explained by imposed travel restrictions. In general, the prior studies analyzed the effects of the macroeconomic variable on stock markets worldwide. However, less study examines the impact of GEPU, GPR and oil prices in ASEAN countries that are rapidly developing emerging economies and a prosperous nation in controlling the pandemic and reviving the stock market. This gap in the literature and the potential development of the ASEAN stock market motivated this study. Hence, it shows a gap knowledge, which needs to be fulfilled to understand these variables' effects as a global factor risk, on stock returns, to make better investment strategies and asset pricing. Grounded on the motivating facts, the stock market behaviors and the knowledge gaps, this study investigates the impacts of GEPU, GPR and oil 
MANAGEMENT SCIENCES

Vol. 12, No. 1, 2022, E-ISSN: 2225-8329 @ 2022 HRMARS

price on ASEAN country's stock returns in regime shifts/environments using Markov Switching model regression.

\section{Data and Preliminary Analysis}

The purpose of this study is to look at how the ASEAN stock market is affected by global economic policy uncertainty (GEPU), geopolitical risk (GPR), and oil prices. As a result, the data for this study is based on monthly data from January 1997 to July 2020. The monthly GEPU index makes it easier to choose the data frequency for the study sample. The data availability on the stock indices taken from the DataStream determines the sample period. Malaysia, Thailand, Indonesia, the Philippines, and Vietnam are among the ASEAN countries that have been chosen. These countries were chosen based on stock price data availability. To construct stock market returns series, stock market prices are changed as follows.

$$
R_{, t}=\operatorname{In}\left(\frac{P_{t}}{P_{t-1}}\right) \times 100
$$

where $R_{t}$ is stock market return.

$$
\begin{aligned}
& G E P U_{i, t}=\operatorname{In}\left(\frac{G E P U_{t}}{G E P U_{t-1}}\right) \times 100 \\
& G P R_{i, t}=\operatorname{In}\left(\frac{G P R_{t}}{G P R_{t-1}}\right) \times 100 \\
& W T I_{i, t}=\operatorname{In}\left(\frac{W T I_{t}}{W T I_{t-1}}\right) \times 100
\end{aligned}
$$

where $R_{t}$, denotes monthly stock returns of the industry for time t. $P_{t}$ and $P_{t-1}$ represents the spot price of stock and price of the previous stock month, respectively. GEPU ${ }_{i, t}, G E P U_{t}$ and GEPU $t_{t-1}$ represent monthly global economic uncertainty, spot points of GEPU index, and previous month's points of GEPU index, respectively. GPR $R_{i, t}, G P R_{t}$ and $G P R_{t-1}$ represent a monthly geopolitical risk, spot points of GPR index, and previous month's points of GPR index, respectively. $W T I, W T I_{t}$ and $W T I_{t-1}$ represent monthly oil price changes or returns, spot oil price, and an oil price of the previous month, respectively.

Prior proceeding to the empirical estimation and analyses, this study has conducted some preliminary analyses regarding normality, correlation analysis, and dynamic of influential variables with graphical analysis.

\section{[Insert Table 1]}

Table 1 shows measures of normality result for kurtosis and all the variables has a long right tail (positive skewness) and leptokurtic. The results of Jarque-Bera normality test shows all statistical distribution of all the variables is not normally distributed.

\section{[Insert Table 2]}

Given the correlation matrix in Table 3, this paper anticipates that GEPU is negatively correlated with stock market returns and oil price. This paper also observes that oil price has negative correlation with GEPU. Figure 1 presents a graphical illustration of the data used in this paper.

\section{[Insert Figure 1]}

In order to test linearity in sectoral return series, this study used the BDS test as recommended by Brooks (1996) and Broock et al., (1996). This "BDS test is based on the concept of a correlation integral. A correlation integral is a measure of the frequency with which temporal patterns are repeated in the data" Basher et al., (2016). Table 4 reports BDS statistics for embedded dimensions and different epsilon values for returns series data and 
MANAGEMENT SCIENCES

Vol. 12, No. 1, 2022, E-ISSN: 2225-8329 @ 2022 HRMARS

stock market returns series data. The plots of stock returns (Figure 2) and BDS test suggest the nonlinear pattern in the market returns series data. Therefore, this paper corroborates the use of nonlinear methods, where data may follow regime shift behavior.

\section{Empirical Framework}

\section{[Insert Table 3]}

Hamilton's (1989, 2010) Markov Regime Switching (hereafter refer to MS) model is one of the most popular nonlinear time series models, allowing time-varying effects across regimes. This model is very efficient when exogenous events drive most of the adjustments. Recently, Arouri (2016) has employed the MS model in estimating the impacts of EPU on U.S. stock market. Therefore, for finding nonlinear effects of GEPU, we adopt MS dynamic regression model, which considers that the influences of transition variables on market returns are stated (st) dependent. The unobservable Markov chain describes the transition from one state to another state. Henceforth, as shown below, Equation (5) is reformulated for MS regression model (Hoque and Zaidi, 2018).

$$
\begin{gathered}
R_{i, s, t}=\gamma_{0, i, s_{t}}+\gamma_{1, i, s_{t}} M K T_{i, t}++\gamma_{2, i, s_{t}} \Delta G E P U_{i, t}+\gamma_{3, i, s_{t}} \Delta G E P U_{i, t-1}+\gamma_{4, i, s_{t}} \Delta G P R_{i, t}+ \\
\gamma_{5, i, s_{t}} \Delta G P R_{i, t-1} \gamma_{6, i, s_{t}} \Delta W T I_{i, t}+\gamma_{7,0, s_{t}} W T I_{i, t-1}+\varepsilon_{i, t} ; \quad \varepsilon_{i, t} \sim N\left(0, \sigma^{2}\right),
\end{gathered}
$$

where, $s$ denotes regime states and all other specifications are same as in specification Equation (5). In this model, the estimation allows all coefficients of the variables to moves between the different regimes.

The process and formulation of M.S. regressions are employed as recommend in Hamilton (1989, 2010, \& 2016) and Agnello et al. (2015). This study conjectures two states, such as low- and high-volatile regimes, in terms of a regime shift. It is also conjecture that the stochastic regime generating process follows an unobservable first-order Markov chain with a two-state regime and time-varying transition probabilities. The time-varying transition probability Markov-Switching models are jointly estimated with maximum likelihood (Diebold et al., 1994; Kim and Yoo, 1995). Where conditional probability of given state, $t$, depends on state-observed prior time, $P\{s t \mid s t-1\}$, and transition from one regime to another depends on the observation of a transition variable, $m t$ so that $P\{S t \mid S t-1\}=P\{S t \mid S t-1, m t\}$. Hence, this study defines the time-varying transition probability of a two-state M.S. model as follows.

$$
\left|z_{t}\right|=\left\{\begin{array}{ll}
P_{11}\left(m_{t-k}\right)=\frac{\exp \left(a_{1}+b_{1} m_{t-k}\right)}{1+\exp \left(a_{1}+b_{1} m_{t-k}\right)} ; & P_{22}\left(m_{t-k}\right)=\frac{\exp \left(a_{2}+b_{2} m_{t-k}\right)}{1+\exp \left(a_{2}+b_{2} m_{t-k}\right)} \\
P_{12}\left(m_{t-k}\right)=1-P_{11}\left(m_{t-k}\right) \quad ; & P_{21}\left(m_{t-k}\right)=1-P_{22}\left(m_{t-k}\right)
\end{array},\right.
$$

where $\operatorname{pij}(m t-k)$ is the probability of moving from regime $i$ to regime $j$ and conditional on the dynamics of the transition variable $k$ periods before, the transition probability pij $(z t-k)$ facilitates in estimating the expected duration of each regime, which is presented below in Equation (7).

$$
D_{i j}=\left(1 / 1-p_{i j}\right)
$$


MANAGEMENT SCIENCES

Vol. 12, No. 1, 2022, E-ISSN: 2225-8329 @ 2022 HRMARS

\section{Estimation Process}

In the estimation of MS model, using a maximum likelihood procedure is suggested. So, this study defines a vector of observed independent variables and transition variables up to period $\mathrm{t}$ as $\psi_{t}=\left(x_{t}, m_{t-k}\right)$. Similarly, this study defines the vector of an endogenous variable's historical values as $\xi_{t}=\left(y_{t}, y_{t-1}, \ldots, y_{1}\right)$. With designating $\vartheta$, the study defines the conditional likelihood function of the observed data, $\xi_{t}$, as follows.

Where

$$
L(\theta)=\pi_{t-1}^{T} f\left(y_{t} \mid \psi_{t,} \xi_{t-1}, \theta,\right) \mid
$$

$$
f\left(y_{t} \mid \psi_{t,} \xi_{t-1,}, \theta,\right) \mid=\sum_{i} \sum_{j} f\left(y_{t}\left|S_{t}=i, S_{t-1}=j, \psi_{t-1, \xi_{t-1}, \theta}\right|\right.
$$

Applying the Bayes's rule, this study recursively calculates the weighted probability with the following Equation (9).

This study also has the following,

$$
\begin{aligned}
p\left(S_{t}\right. & \left.=i \mid S_{t-1}=j, z_{t}\right) p\left(S_{t-1}=j \mid \psi_{t} \xi_{t-1}: \theta\right) \\
& =p_{i j}\left(z_{t}\right)\left(S_{t-1}=j \mid \psi_{t}, \xi_{t-1,}, \theta,\right) \mid
\end{aligned}
$$

$$
\begin{aligned}
p\left(S_{t}=j \mid \psi_{t+1} \xi_{1}: \theta\right. & =p\left(S_{t}=j \mid \psi_{t} \xi_{t}: \theta\right) \times \frac{1}{f\left(y_{t \mid \psi_{t}} \xi_{t-1}: \theta\right.} \\
\sum j f\left(y_{t} \mid S_{t}\right. & \left.=i,\left|S_{t-1}=j,\right| \psi_{t-1} \xi_{t-1}: \theta\right) \\
\times & p\left(S_{t}=1, S_{t-1}=j \psi_{t} \xi_{t-1}: \theta\right)
\end{aligned}
$$

Henceforth, in order to complete and define recursion in Equations (9) and (10), this study defines the regime- dependent conditional density functions as follows:

$$
\begin{aligned}
& f\left(y_{t}\left|S_{t}=1,\right| S_{t-1}=j, \mid \psi_{t-1} \xi_{t-1}: \theta\right)=\frac{\varphi\left(y_{t}-\frac{\chi_{t} \beta_{1}}{\sigma_{1}}\right)}{\sigma_{1} p_{1 j}\left(z_{t}\right)} \\
& f\left(y_{t}\left|S_{t}=2,\right| S_{t-1}=j, \mid \psi_{t-1} \xi_{t-1}: \theta\right)=\frac{\varphi\left(y_{t}-\frac{\chi_{t} \beta_{2}}{\sigma_{2}}\right)}{\sigma_{2} p_{21 j}\left(z_{t}\right)}
\end{aligned}
$$

\section{Empirical Analysis and Discussions}

With the premise of two different volatility regimes in stock returns, this work estimates M.S. dynamic regression models. Low and high volatility regimes are referred to as Regimes 1 and 2, respectively. The estimated findings of two states MS dynamic regression models, as well as the effects of risk variables on market returns, are presented in Table 5. To verify the existence of a volatility regime, this study first examines standard deviations (sigma), which have a highly significant sigma coefficient for all stock markets. These data suggest that the stock market is divided into two regimes or states. Both graphical analysis and the BDS test, as shown in Figure 2 and Table 4, corroborate these findings. The major goal of the research is to see how GEPU, GPR, and oil prices affect stock market returns. We can predict distinct possible reactions in different regimes if the data behaviour is nonlinear. Table 5 shows the estimated coefficients for the independent variables in columns 4, 5, and 6 . Focusing on the effects of GEPU, this paper discovers that it has a considerable negative effect on JSE, KLCl, and SET in state 1 (low regime). These findings are in line with those of Phan et al. (2018), who showed a negative impact on Japan and the Netherlands. Furthermore, regardless of the regime, the findings of GEPU's negative effect are consistent with numerous previous empirical research (Antonakakis et al., 2013; Arouri et al., 2014 \& 2016, Chang et al., 2015; Kang et al., 2017). In contrast to Yu et al., (2018), GEPU has a positive and considerable impact on the volatility of the Chinese stock market. GPR has no discernible impact on ASEAN stock indices. Axel (2020) came to the same conclusion, indicating that geopolitical risk had 
MANAGEMENT SCIENCES

Vol. 12, No. 1, 2022, E-ISSN: 2225-8329 @ 2022 HRMARS

no impact on return or volatility spillovers. Unlike Balcilar et al. (2018), the effect of geopolitical risks is diverse across the BRICS stock markets, implying that news about geopolitical tensions does not have a consistent impact on return dynamics in these markets. According to Antonakakis et al., (2017), geopolitical risk has a negative impact on oil returns and volatility, as well as the covariance between the two markets to a lesser extent.

\section{[Insert Table 4]}

Table 4 indicates that rising oil prices have significant positive effects on the JSE, KLCl, and PSI in state 1 , but negative effects on the SET and VNI in state 2 . It demonstrates that a higher oil price will result in a higher stock return in a low regime for three ASEAN countries, particularly Malaysia as an oil exporter. Rising oil prices, contrary to popular belief, have a stronger negative impact on stock returns (You et al., 2017). According to Alsalman (2016), there is no statistically significant influence of oil price volatility on stock returns in the United States. Furthermore, when looking at Table 5 for time-varying transition probabilities, this study notices that transitioning from one state to another has probabilities. The high volatility regime usually lasts longer than the low volatility regime. In a graphical depiction of the smoothed regime probabilities, these identical representations also exist. The smoothed regime probabilities for the low and high volatility regimes (Figure 3 ) reveal that the 2008/2009 and post-crisis financial crises were the primary causes of high volatility in stock returns across the board. This study, with the exception of the GEPU risk factor, focuses on the effects of risk factors on stock returns under the two regimes.

\section{[Insert Table 5]}

The transition probability matrix and predicted durations are shown here. It's worth noting that the transition probabilities are highly state dependent, with a larger possibility of continuing in the high volatility regime. For the Jakarta Stock Exchange, the comparable expected durations in a regime are around 4.93 months in a low volatility regime and 5.476 months in a high volatility regime (JSE). In high volatility regimes, the projected length for $\mathrm{KLCl}, \mathrm{PSI}, \mathrm{SET}$, and $\mathrm{VNI}$ is $11,10,24$, and 73 months, respectively. Overall, this research finds that GEPU, GPR, and oil price have time-varying asymmetric and regime-varying nonlinear effects on ASEAN countries' indices. In the low volatility environment, the impact of GEPU is primarily negative and considerable. As a result of the large influence, changes in GEPU have an impact on the investor mind by creating sensitivities about future stock return uncertainty.

\section{Robustness Testing}

This section further subjects the regression results to robustness checks and the essence is to evaluate the sensitivity of the regression results. We use a nonlinear ARDL (NARDL) model for this study because it can account for asymmetry in a nonlinear fashion by computing the positive and negative partial sum decompositions of the relevant explanatory variable(s). The computational advantages of using this approach in modelling economic relationships are well documented in (Nusair, 2016). Although the nonlinear ARDL model is the panel representation of the Shin et al. (2014) model proposed for time series, it is analogous to the heterogeneous panel data model except that the latter assumes a linear relationship between variable and stock price. Thus, this study accounts for nonlinearities by decomposing the variables series into positive and negative changes.

$$
r_{t}=\alpha_{0}+\alpha_{1} G E P U_{t}^{+}+\alpha_{2} G E P U_{t}^{-}+\alpha_{3} G P R_{t}^{+}+\alpha_{4} G P R_{t}^{-}+\alpha_{5} W T I_{t}^{+}+W T I_{t}^{-}+\varepsilon_{t}
$$


MANAGEMENT SCIENCES

Vol. 12, No. 1, 2022, E-ISSN: 2225-8329 @ 2022 HRMARS

The estimated results in Table 7 show that the impact of GEPU is significant to JSE, KLCI and SET, which supports the result of Markov Switching Model in Table 5. GPR robustness test result also consistent with the Markov result, which shows no significant impact on any stock market return. The result of oil price also in line with the Markov because it shows a significant impact on JSE, KLCI, PSI, SET and VNI. These findings provide strong support that low and high volatility regimes exist in all ASEAN stock indices.

\section{Conclusion}

[Insert Table 6]

The effects of GEPU, GPR, and oil price (WTI) on ASEAN stock market indices are examined in this study from January 2007 to July 2020. Using the Markov Switching Model to find the impact of these independent variables on the ASEAN stock indices, more focus was paid to the regime dependent nonlinear interaction between GEPU, GPR, and oil price on the ASEAN stock indices. NARDL results corroborated these conclusions. The following are the key findings of this paper. The GEPU and oil prices, for starters, have a considerable negative impact on the bulk of ASEAN stock indices. Second, contrary to earlier research, GPR has no discernible effect on the ASEAN stock market. It could be owing to the fact that minor geopolitical events inside the ASEAN region have a minimal strategic impact on financial markets, even though they have the capacity to shape economic trends over time. Third, the price of oil (WTI) has a large impact on all of these stock indexes in the high-volatility regime, which is much higher than the low-volatility regime. The majority of the GEPU has a negative impact on both regimes that have risk aversion to GEPU risk, regardless of market or volatility conditions. The empirical findings reported in this study may be useful to a variety of economic organisations for various purposes. To begin with, the findings of this study may be valuable to investors and portfolio managers in terms of hedging and determining optimal portfolios. Second, the outcomes of this study may be valuable to a corporate risk manager in determining if GEPU, GPR, and oil price are systematic risk factors in stock returns or not. Third, the findings of this study may help policymakers comprehend the importance of GEPU transmission, which is a significant input in the development of economic and financial policies. 
MANAGEMENT SCIENCES

Vol. 12, No. 1, 2022, E-ISSN: 2225-8329 @ 2022 HRMARS

\section{References}

Agnello, L., Dufrénot, G., \& Sousa, R. M. (2015). Nonlinear effects of asset prices on fiscal policy: Evidence from the U.K., Italy and Spain. Economic Modelling, 44, 358-362.

Ahmad, W., \& Sharma, S. K. (2018). Testing output gap and economic uncertainty as an explicator of stock market returns. Research in International Business and Finance, 45, 293-306.

Alsalman, Z. (2016). Oil price uncertainty and the U.S. stock market analysis based on a GARCH-in-mean VAR model. Energy Economics, 59, 251-260.

Antonakakis, N., Chatziantoniou, I., \& Filis, G. (2013). Dynamic co-movements of stock market returns, implied volatility and policy uncertainty. Economics Letters, 120(1), 87-92.

Antonakakis, N., Chatziantoniou, I., \& Filis, G. (2014). Dynamic spillovers of oil price shocks and economic policy uncertainty. Energy Economics, 44, 433-447.

Antonakakis, N., Gupta, R., Kollias, C., \& Papadamou, S. (2017). Geopolitical Risks and the OilStock Nexus Over 1899-2016. Finance Research Letter (Forthcoming)., 23, 165-173.

Arouri, M., Estay, C., Rault, C., \& Roubaud, D. (2016). Economic policy uncertainty and stock markets: Long-run evidence from the U.S. Finance Research Letters, 18, 136-141.

Baker, S. R., Bloom, N., \& Davis, S. J. (2016). Measuring economic policy uncertainty. The Quarterly Journal of Economics, 131(4), 1593-1636.

Balcilar, M., Bonato, M., Demirer, R., \& Gupta, R. (2018). Geopolitical risks and stock market dynamics of the BRICS. Economic Systems, 42(2), 295-306.

Bams, D., Blanchard, G., Honarvar, I., \& Lehnert, T. (2017). Does oil and gold price uncertainty matter for the stock market?. Journal of Empirical Finance, 44, 270-285.

Basher, S. A., Haug, A. A., \& Sadorsky, P. (2016). The impact of oil shocks on exchange rates: a Markov-switching approach. Energy Economics, 54, 11-23.

Broock, W. A., Scheinkman, J. A., Dechert, W. D., \& LeBaron, B. (1996). A test for independence based on the correlation dimension. Econometric Reviews, 15(3), 197235

Brooks, C. (1996). Testing for non-linearity in daily sterling exchange rates. Applied Financial Economics, 6(4), 307-317. https://doi.org/10.1080/096031096334105

Caldara, D., \& lacoviello, M. (2018). Measuring geopolitical risk. FRB International Finance Discussion Paper, (1222).

Cepni, O., Guney, I. E., \& Swanson, N. R. (2020). Forecasting and nowcasting emerging market GDP growth rates: The role of latent global economic policy uncertainty and macroeconomic data surprise factors. Journal of Forecasting, 39(1), 18-36.

Chang, T., Chen, W. Y., Gupta, R., \& Nguyen, D. K. (2015). Are stock prices related to the political uncertainty index in OECD countries? Evidence from the bootstrap panel causality test. Economic Systems, 39(2), 288-300.

Davis, S. J. (2016). An index of global economic policy uncertainty (No. w22740). National Bureau of Economic Research

Diebold, F. X., Lee, J. H., \& Weinbach, G. C. (1994). Regime switching with time-varying transition probabilities (pp. 144-165). Business Cycles: Durations, Dynamics, and Forecasting.

Dimic, N., Kiviaho, J., Piljak, V., \& Äijö, J. (2016). Impact of financial market uncertainty and macroeconomic factors on stock-bond correlation in emerging markets. Research in International Business and Finance, 36, 41-51. 
MANAGEMENT SCIENCES

Vol. 12, No. 1, 2022, E-ISSN: 2225-8329 ๔ 2022 HRMARS

Fang, L., Chen, B., Yu, H., \& Qian, Y. (2018). The importance of global economic policy uncertainty in predicting gold futures market volatility: A GARCH-MIDAS approach. Journal of Futures Markets, 38(3), 413-422.

Fang, L., Bouri, E., Gupta, R., \& Roubaud, D. (2019). Does global economic uncertainty matter for the volatility and hedging effectiveness of Bitcoin?. International Review of Financial Analysis, 61, 29-36.

Gulen, H., \& Ion, M. (2015). Policy uncertainty and corporate investment. The Review of Financial Studies, 29(3), 523-564.

Hamilton, J. D. (1989). A new approach to the economic analysis of nonstationary time series and the business cycle. Econometrica: Journal of the Econometric Society, 57, 357-384

Hamilton, J. D. (2010). Regime switching models. In Macroeconometrics and time series analysis (pp. 202-209). Palgrave Macmillan UK

$\mathrm{He}$, Q., Liu, J., Wang, S., \& Yu, J. (2020). The impact of COVID-19 on stock markets. Economic and Political Studies, 1-14.

Hoque, M. E., \& Zaidi, M. A. S. (2019). The impacts of global economic policy uncertainty on stock market returns in regime switching environment: Evidence from sectoral perspectives. International Journal of Finance \& Economics, 24(2), 991-1016.

Kang, W., Gracia, F. P., \& Ratti, R. A. (2017b). Oil price shocks, policy uncertainty, and stock returns of oil and gas corporations. Journal of International Money and Finance, 70, 344-359

Kang, W., \& Ratti, R. A. (2013). Oil shocks, policy uncertainty and stock market return. Journal of International Financial Markets, Institutions and Money, 26, 305-318.

Kang, W., Ratti, R. A., \& Vespignani, J. L. (2017a). Oil price shocks and policy uncertainty: New evidence on the effects of U.S. and non-US oil production. Energy Economics., 66, 536546

Kim, M. J., \& Yoo, J. S. (1995). New index of coincident indicators: A multivariate Markov switching factor model approach. Journal of Monetary Economics, 36(3), 607-630.

Li, T., Ma, F., Zhang, X., \& Zhang, Y. (2020). Economic policy uncertainty and the Chinese stock market volatility: Novel evidence. Economic Modelling, 87, 24-33.

Liu, Q., Xu, W., Lu, S., Jiang, J., Zhou, J., Shao, Z. ... \& Jin, S. (2018). Landscape of emerging and re-emerging infectious diseases in China: impact of ecology, climate, and behavior. Frontiers of medicine, 12(1), 3-22.

Mora, A. (2019). The Spillover Effects of Global Economic Policy Uncertainty (GEPU) on Emerging Equity Markets: Evidence from Thailand (Doctoral dissertation, NIDA).

Nusair, S. A. (2016). The effects of oil price shocks on the economies of the Gulf Co-operation Council countries: Nonlinear analysis. Energy Policy, 91, 256-267.

Oad Rajput, S. K., Wongchoti, U., Chen, J., \& Faff, R. (2019). Is Financial Flexibility a Priced Factor in the Stock Market?. Financial Review, 54(2), 345-375.

Sharif, A., Aloui, C., \& Yarovaya, L. (2020). COVID-19 pandemic, oil prices, stock market, geopolitical risk and policy uncertainty nexus in the U.S. economy: Fresh evidence from the wavelet-based approach. International Review of Financial Analysis.

Shin, Y., Yu, B., \& Greenwood-Nimmo, M. (2014). Modelling asymmetric cointegration and dynamic multipliers in a nonlinear ARDL framework. In Festschrift in honor of Peter Schmidt (pp. 281-314). Springer, New York, NY.

Smales, L. A. (2019). Geopolitical Risk and Volatility Spillovers in Oil and Stock Markets. Available at SSRN 3414134. 
Tsai, I. C. (2017). The source of global stock market risk: A viewpoint of economic policy uncertainty. Economic Modelling, 60, 122-131.

Yang, M., \& Jiang, Z. Q. (2016). The dynamic correlation between policy uncertainty and stock market returns in China. Physica A: Statistical Mechanics and Its Applications, 461, 92100.

You, W., Guo, Y., Zhu, H., \& Tang, Y. (2017). Oil price shocks, economic policy uncertainty and industry stock returns in China: Asymmetric effects with quantile regression. Energy Economics, 68, 1-18.

Yu, H., Fang, L., \& Sun, W. (2018). Forecasting performance of global economic policy uncertainty for the volatility of the Chinese stock market. Physica A: Statistical Mechanics and its Applications, 505, 931-940.

Yu, M., \& Song, J. (2018). Volatility forecasting: Global economic policy uncertainty and regime-switching. Physica A: Statistical Mechanics and its Applications, 511, 316-323.

Table 1:

Descriptive statistic and normality test

\begin{tabular}{|c|c|c|c|c|c|c|c|c|}
\hline & $\begin{array}{c}\text { Mea } \\
n\end{array}$ & $\begin{array}{c}\text { Media } \\
n\end{array}$ & $\begin{array}{c}\text { Maximu } \\
\mathrm{m}\end{array}$ & $\underset{\mathrm{m}}{\operatorname{Minimu}}$ & $\begin{array}{l}\text { Std. } \\
\text { Dev. }\end{array}$ & $\begin{array}{c}\text { Skewnes } \\
\mathrm{s}\end{array}$ & $\begin{array}{c}\text { Kurtosi } \\
\mathrm{s}\end{array}$ & $\begin{array}{c}\text { Jarque- } \\
\text { Bera }\end{array}$ \\
\hline \multicolumn{9}{|l|}{ GEP } \\
\hline$U$ & 1.02 & 0.32 & 62.47 & -49.61 & 19.09 & 0.45 & 3.97 & $\begin{array}{c}11.90 \\
(0.00)^{* *} \\
*\end{array}$ \\
\hline GPR & 0.02 & -2.37 & 115.62 & -111.82 & 34.02 & 0.45 & 4.55 & $\begin{array}{c}21.69 \\
(0.00)^{* *} \\
*\end{array}$ \\
\hline WTI & -0.18 & 1.44 & 53.83 & -57.52 & 11.91 & -0.96 & 10.21 & $\begin{array}{c}375.57 \\
(0.00)^{* *} \\
*\end{array}$ \\
\hline JSE & 0.66 & 1.29 & 18.34 & -37.72 & 5.94 & -1.83 & 13.58 & $\begin{array}{c}846.54 \\
(0.00)^{* *} \\
*\end{array}$ \\
\hline $\mathrm{KLCl}$ & 0.18 & 0.54 & 12.70 & -16.51 & 3.49 & -0.71 & 6.61 & $\begin{array}{c}101.62 \\
(0.00)^{* *} \\
*\end{array}$ \\
\hline PSI & 0.37 & 1.18 & 13.95 & -27.54 & 5.51 & -1.36 & 8.34 & $\begin{array}{c}242.78 \\
(0.00)^{* *} \\
*\end{array}$ \\
\hline SET & 0.44 & 1.06 & 14.51 & -35.92 & 5.94 & -1.68 & 11.16 & $\begin{array}{c}526.90 \\
(0.00)^{* *} \\
*\end{array}$ \\
\hline VNI & $\begin{array}{c}- \\
0.164\end{array}$ & 0.33 & 24.67 & -28.63 & 8.28 & -0.65 & 4.94 & $\begin{array}{c}37.08 \\
(0.00)^{* *} \\
*\end{array}$ \\
\hline
\end{tabular}


INTERNATIONAL JOURNAL OF ACADEMIC RESEARCH IN ACCOUNTING, FINANCE AND MANAGEMENT SCIENCES

Vol. 12, No. 1, 2022, E-ISSN: 2225-8329 @ 2022 HRMARS

\section{Table 2}

\section{Correlation matrix}

\begin{tabular}{llllllll}
\hline GEPU & GPR & JSE & KLCI & PSI & SET & VNI & WTI \\
\hline
\end{tabular}

\begin{tabular}{|c|c|c|c|c|c|c|c|}
\hline GEPU & 1 & & & & & & \\
\hline GPR & 0.02 & 1 & & & & & \\
\hline JSE & -0.27 & 0.13 & 1 & & & & \\
\hline $\mathrm{KLCl}$ & -0.30 & 0.12 & 0.72 & 1 & & & \\
\hline PSI & -0.17 & 0.05 & 0.73 & 0.61 & 1 & & \\
\hline SET & -0.22 & 0.13 & 0.77 & 0.64 & 0.67 & 1 & \\
\hline VNI & -0.16 & 0.11 & 0.40 & 0.36 & 0.47 & 0.42 & 1 \\
\hline WTI & -0.19 & 0.11 & 0.28 & 0.27 & 0.27 & 0.25 & 0.23 \\
\hline
\end{tabular}

Figure 1: Raw data time series of ASEAN stock indices, GEPU, GPR and WTI

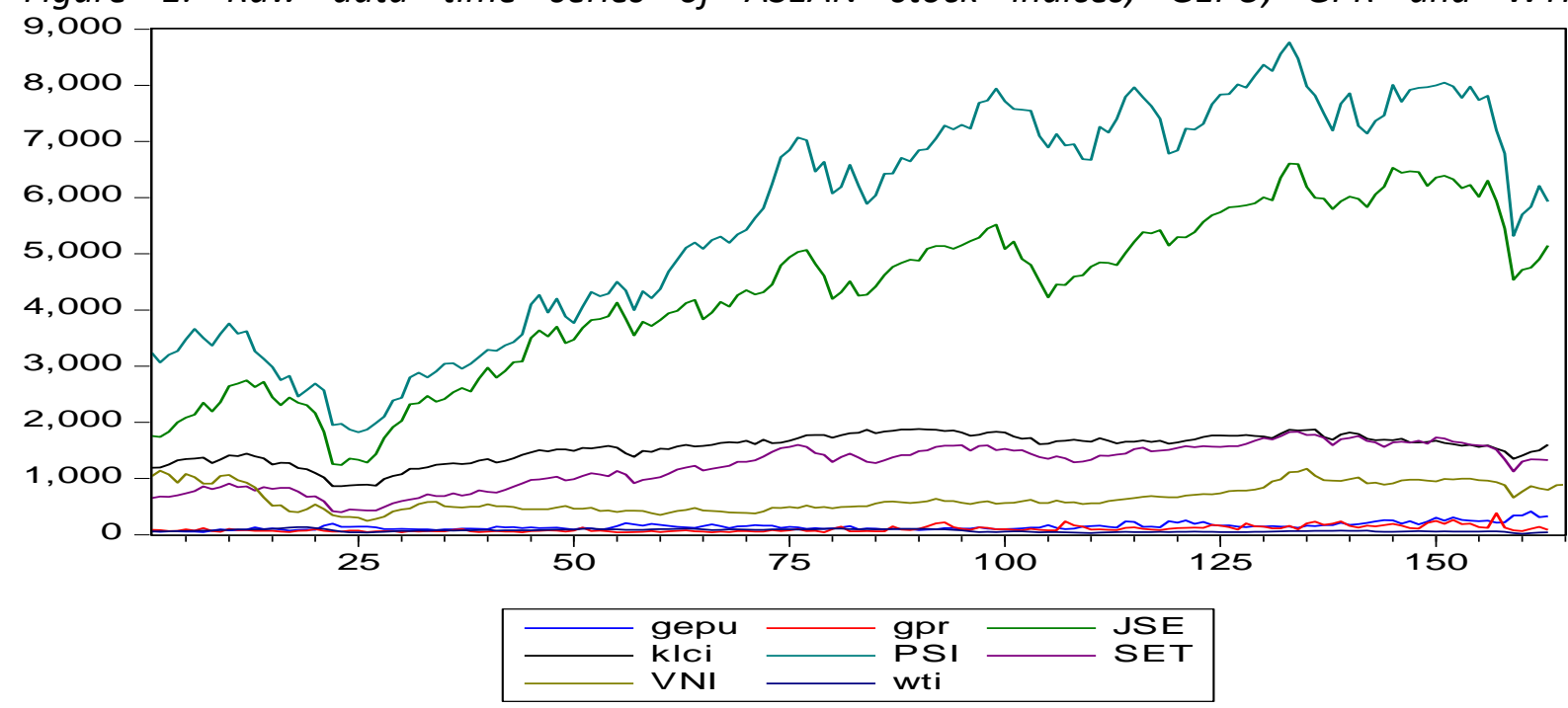

Table 3:

BDS Test result

\begin{tabular}{cccccc}
\cline { 2 - 6 } & $\mathrm{m}=2$ & $\mathrm{~m}=3$ & $\mathrm{~m}=4$ & $\mathrm{~m}=5$ & $\mathrm{~m}=6$ \\
\hline GEPU & $0.008^{* * *}$ & $0.012^{* *}$ & $0.016^{* *}$ & $0.016^{* *}$ & $0.010^{* *}$ \\
GPR & $0.008^{* * *}$ & $0.018^{* *}$ & $0.016^{* *}$ & $0.016^{* *}$ & $0.013^{* *}$ \\
WTI & 0.053 & 0.080 & 0.091 & 0.088 & 0.079 \\
JSE & $0.024^{* *}$ & $0.045^{* *}$ & 0.058 & 0.064 & 0.062 \\
KLCI & $0.010^{* * *}$ & $0.032^{* *}$ & $0.045^{* *}$ & 0.052 & $0.047^{* *}$ \\
PSI & $0.002^{* * *}$ & $0.023^{* *}$ & $0.037^{* *}$ & $0.045^{* *}$ & $0.042^{* *}$ \\
SET & $0.027^{* *}$ & $0.046^{* *}$ & 0.053 & 0.052 & $0.048^{* *}$ \\
VNI & $0.033^{* *}$ & 0.061 & 0.087 & 0.099 & 0.100 \\
\hline
\end{tabular}

Notes: $* * *$ and $* *$ represents significant at $1 \%$ and $5 \%$ level. 
INTERNATIONAL JOURNAL OF ACADEMIC RESEARCH IN ACCOUNTING, FINANCE AND MANAGEMENT SCIENCES

Vol. 12 , No. 1, 2022, E-ISSN: 2225-8329 @ 2022 HRMARS

Figure 2: Times series plots of variables
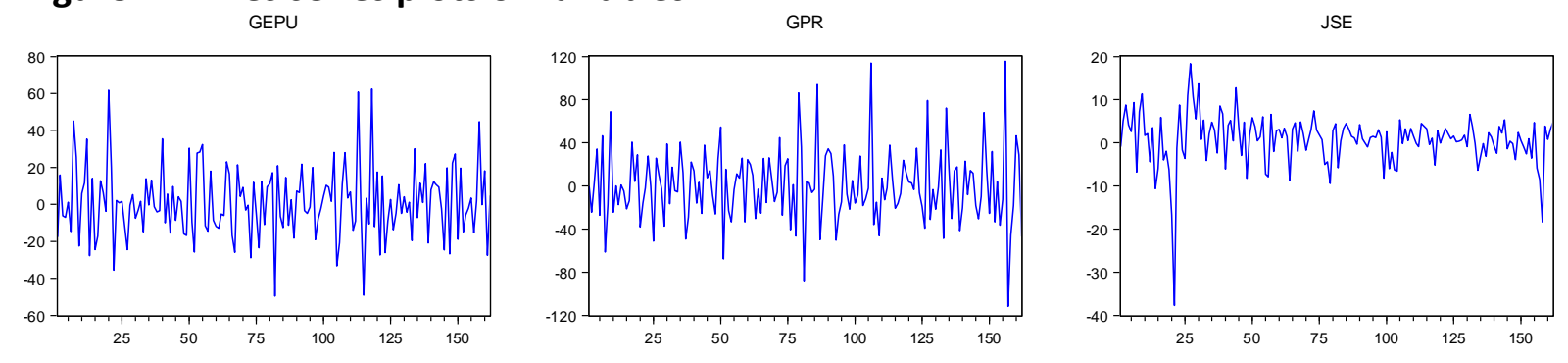

$\mathrm{KLCl}$

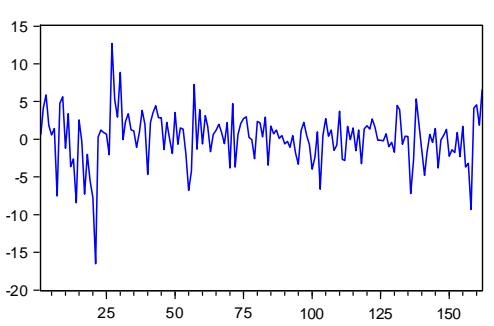

PSI

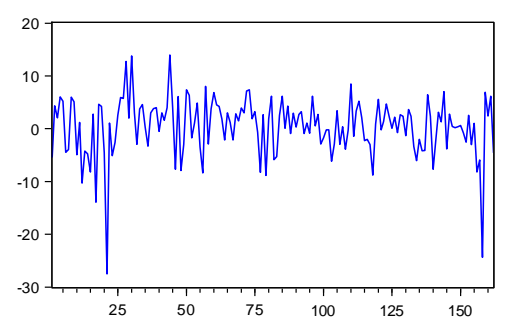

SET
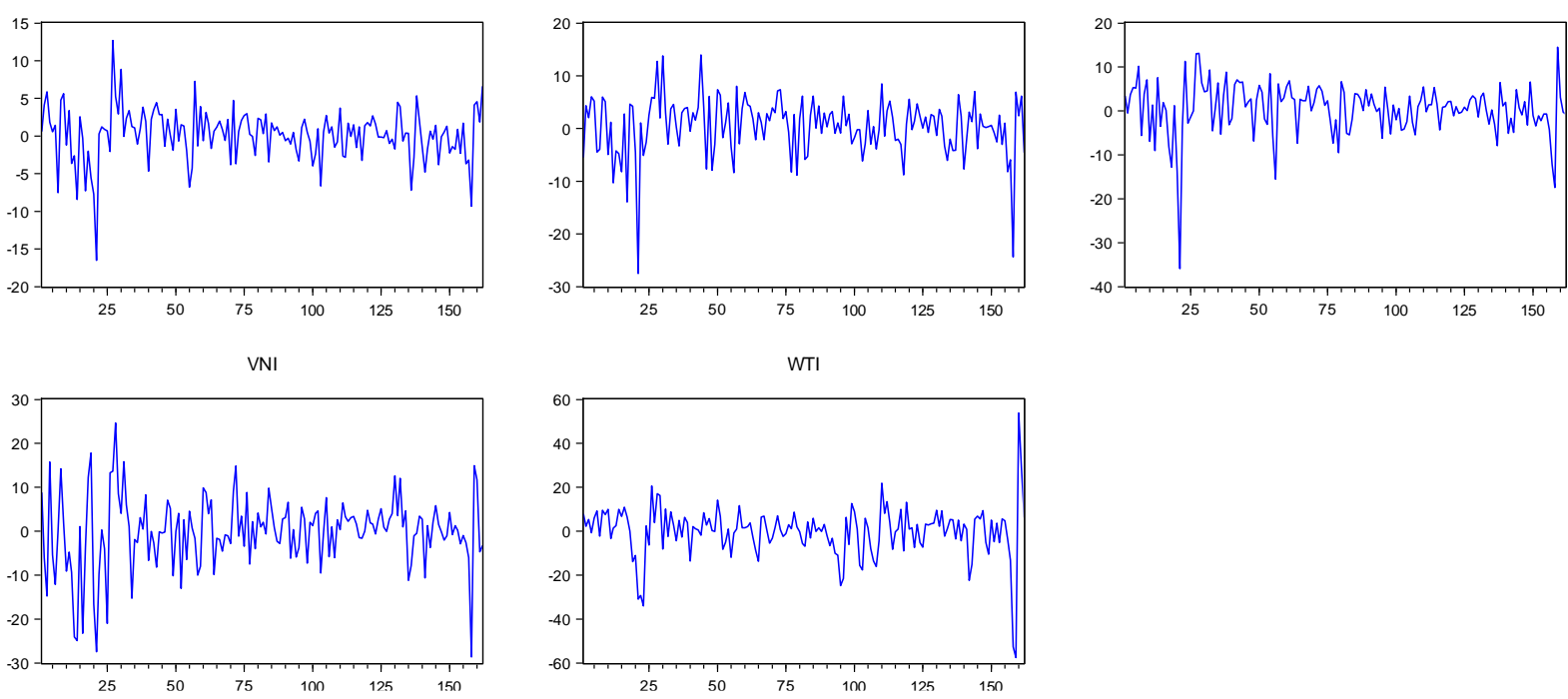

Table 4: Result of Markov Switching

\begin{tabular}{|c|c|c|c|c|c|c|c|}
\hline Indices & State & Intercept & GEPU & GPR & WTI & SIGMA & LL \\
\hline JSE & S1 & $\begin{array}{l}-0.220 \\
(0.818)\end{array}$ & $\begin{array}{l}-0.108 \\
(0.034)^{* *}\end{array}$ & $\begin{array}{l}0.023 \\
(0.364)\end{array}$ & $\begin{array}{l}0.311 \\
(0.042)^{* *}\end{array}$ & $\begin{array}{l}1.867 \\
(0.000)^{* * *}\end{array}$ & -476.093 \\
\hline & S2 & $\begin{array}{l}1.736 \\
(0.000)^{* * *}\end{array}$ & $\begin{array}{l}0.021 \\
(0.374)\end{array}$ & $\begin{array}{l}0.006 \\
(0.631)\end{array}$ & $\begin{array}{l}-0.023 \\
(0.448)\end{array}$ & $\begin{array}{l}0.811 \\
(0.000)^{* * *}\end{array}$ & \\
\hline $\mathrm{KLCl}$ & S1 & $\begin{array}{l}0.033 \\
(0.958)\end{array}$ & $\begin{array}{l}-0.106 \\
(0.002)^{* * *}\end{array}$ & $\begin{array}{l}0.000 \\
(0.960)\end{array}$ & $\begin{array}{l}0.072 \\
(0.072) *\end{array}$ & $\begin{array}{l}1.467 \\
(0.000)^{* * *}\end{array}$ & -403.77 \\
\hline & S2 & $\begin{array}{l}0.478 \\
(0.064)^{*}\end{array}$ & $\begin{array}{l}-0.010 \\
(0.402)\end{array}$ & $\begin{array}{l}0.005 \\
(0.430)\end{array}$ & $\begin{array}{l}0.039 \\
(0.244)\end{array}$ & $\begin{array}{l}0.659 \\
(0.000)^{* * *}\end{array}$ & \\
\hline PSI & S1 & $\begin{array}{l}-5.179 \\
(0.011)^{* *}\end{array}$ & $\begin{array}{l}-0.023 \\
(0.677)\end{array}$ & $\begin{array}{l}-0.035 \\
(0.164)\end{array}$ & $\begin{array}{l}0.418 \\
(0.000)^{* * *}\end{array}$ & $\begin{array}{l}1.551 \\
(0.000)^{* * *}\end{array}$ & -482.57 \\
\hline & S2 & $\begin{array}{l}1.625 \\
(0.001)^{* * *}\end{array}$ & $\begin{array}{l}-0.011 \\
(0.641)\end{array}$ & $\begin{array}{l}0.009 \\
(0.478)\end{array}$ & $\begin{array}{l}0.037 \\
(0.274)\end{array}$ & $\begin{array}{l}1.376 \\
(0.000)^{* * *}\end{array}$ & \\
\hline SET & S1 & $\begin{array}{l}-1.067 \\
(0.571)\end{array}$ & $\begin{array}{l}-0.162 \\
(0.055)^{*}\end{array}$ & $\begin{array}{l}0.013 \\
(0.745)\end{array}$ & $\begin{array}{l}0.067 \\
(0.414)\end{array}$ & $\begin{array}{l}2.164 \\
(0.000)^{* * *}\end{array}$ & -486.446 \\
\hline
\end{tabular}




\begin{tabular}{|c|c|c|c|c|c|c|c|}
\hline & S2 & $\begin{array}{l}1.066 \\
(0.007)^{* * *}\end{array}$ & $\begin{array}{l}-0.010 \\
(0.658)\end{array}$ & $\begin{array}{l}0.013 \\
(0.328)\end{array}$ & $\begin{array}{l}0.129 \\
(0.024)^{* *}\end{array}$ & $\begin{array}{l}1.280 \\
(0.00)^{* * *}\end{array}$ & \\
\hline VNI & S1 & $\begin{array}{l}-1.843 \\
(0.389)\end{array}$ & $\begin{array}{l}-0.052 \\
(0.643)\end{array}$ & $\begin{array}{l}0.088 \\
(0.252)\end{array}$ & $\begin{array}{l}0.122 \\
(0.280)\end{array}$ & $\begin{array}{l}2.554 \\
(0.000)^{* * *}\end{array}$ & -538.383 \\
\hline & S2 & $\begin{array}{l}0.541 \\
(0.262)\end{array}$ & $\begin{array}{l}-0.024 \\
(0.365)\end{array}$ & $\begin{array}{l}-0.003 \\
(0.826)\end{array}$ & $\begin{array}{l}0.121 \\
(0.051)^{*}\end{array}$ & $\begin{array}{l}1.622 \\
(0.000)^{* * *}\end{array}$ & \\
\hline
\end{tabular}

Notes: ${ }^{* * *}$ and ${ }^{* *}$ represents significant at $1 \%$ and $5 \%$ level.

Table 5: Result of Markov switching regression's time varying probability and expected duration

\begin{tabular}{lcccccc}
\hline & \multicolumn{3}{l}{ Time-varying transition probability } & \multicolumn{2}{l}{ Expected duration } \\
\hline & Low/Low & Low/High & High/Low & High/High & $\begin{array}{l}\text { Low volatility } \\
\text { regime }\end{array}$ & $\begin{array}{l}\text { High volatility } \\
\text { regime }\end{array}$ \\
\hline & & & & & & \\
JSE & 0.797 & 0.203 & 0.183 & 0.817 & 4.930 & 5.476 \\
$\mathrm{KLCl}$ & 0.857 & 0.143 & 0.0898 & 0.910 & 6.987 & 11.133 \\
$\mathrm{PSI}$ & 0.560 & 0.439 & 0.096 & 0.904 & 2.276 & 10.365 \\
$\mathrm{SET}$ & 0.877 & 0.123 & 0.040 & 0.957 & 8.160 & 24.200 \\
$\mathrm{VNI}$ & 0.982 & 0.018 & 0.014 & 0.986 & 56.670 & 72.700 \\
\hline \multicolumn{7}{l}{} \\
\hline
\end{tabular}

Table 6: Result of Nonlinear ARDL

\begin{tabular}{lcrrrr}
\hline Indices & Variables & Coefficient & Std. Error & t-Statistic & \multicolumn{1}{c}{ Prob. } \\
\hline KLCI & GEPU_POS & -0.052 & 0.014 & -3.701 & $0.000^{* * *}$ \\
& GEPU_NEG & -0.043 & 0.013 & -3.217 & $0.002^{* * *}$ \\
& GPR_POS & 0.007 & 0.007 & 0.984 & 0.326 \\
& GPR_NEG & 0.012 & 0.007 & 1.613 & 0.108 \\
& WTI_POS & 0.063 & 0.023 & 2.696 & $0.007^{* * *}$ \\
& WTI_NEG & 0.018 & 0.026 & 0.697 & 0.486 \\
& & & & & \\
JSE & GEPU_POS & -0.079 & 0.024 & -3.293 & $0.001^{* * *}$ \\
& GEPU_NEG & -0.072 & 0.023 & -3.080 & $0.002^{* * *}$ \\
& GPR_POS & 0.016 & 0.013 & 1.222 & 0.223 \\
& GPR_NEG & 0.019 & 0.012 & 1.519 & 0.130 \\
& WTI_POS & 0.082 & 0.040 & 2.056 & $0.041^{* *}$ \\
& WTI_NEG & 0.047 & 0.045 & 1.034 & 0.302 \\
& & & & & \\
PSI & GEPU_POS & -0.044 & 0.023 & -1.916 & $0.057^{*}$ \\
& GEPU_NEG & -0.033 & 0.022 & -1.491 & 0.137 \\
& GPR_POS & 0.001 & 0.012 & 0.109 & 0.913 \\
& GPR_NEG & 0.007 & 0.012 & 0.569 & 0.570 \\
\hline
\end{tabular}


INTERNATIONAL JOURNAL OF ACADEMIC RESEARCH IN ACCOUNTING, FINANCE AND MANAGEMENT SCIENCES

Vol. 12, No. 1, 2022, E-ISSN: 2225-8329 @ 2022 HRMARS

\begin{tabular}{rrrrrr}
\hline & WTI_POS & 0.126 & 0.037 & 3.356 & $0.001^{* * *}$ \\
& WTI_NEG & 0.070 & 0.042 & 1.642 & 0.102 \\
SET & & & & \\
& GEPU_POS & -0.065 & 0.024 & -2.619 & $0.009^{* * *}$ \\
& GEPU_NEG & -0.054 & 0.024 & -2.233 & $0.027^{* *}$ \\
& GPR_POS & 0.017 & 0.013 & 1.298 & 0.195 \\
& GPR_NEG & 0.022 & 0.013 & 1.672 & $0.096^{*}$ \\
& WTI_POS & 0.082 & 0.044 & 1.8478 & $0.066^{*}$ \\
& WTI_NEG & 0.030 & 0.049 & 0.620 & 0.535 \\
& & & & & \\
VNI & GEPU_POS & -0.054 & 0.035 & -1.552 & 0.122 \\
& GEPU_NEG & -0.044 & 0.034 & -1.311 & 0.191 \\
& GPR_POS & 0.018 & 0.019 & 0.981 & 0.327 \\
& GPR_NEG & 0.021 & 0.018 & 1.121 & 0.263 \\
& WTI_POS & 0.119 & 0.057 & 2.085 & $0.038^{* *}$ \\
\hline \hline
\end{tabular}


INTERNATIONAL JOURNAL OF ACADEMIC RESEARCH IN ACCOUNTING, FINANCE AND MANAGEMENT SCIENCES

Vol. 12 , No. 1, 2022, E-ISSN: 2225-8329 ๔ 2022 HRMARS

Figure 3: Markov Switching Regime Probabilities

Smoothed Regime Probabilities

$P(S(t)=1)$
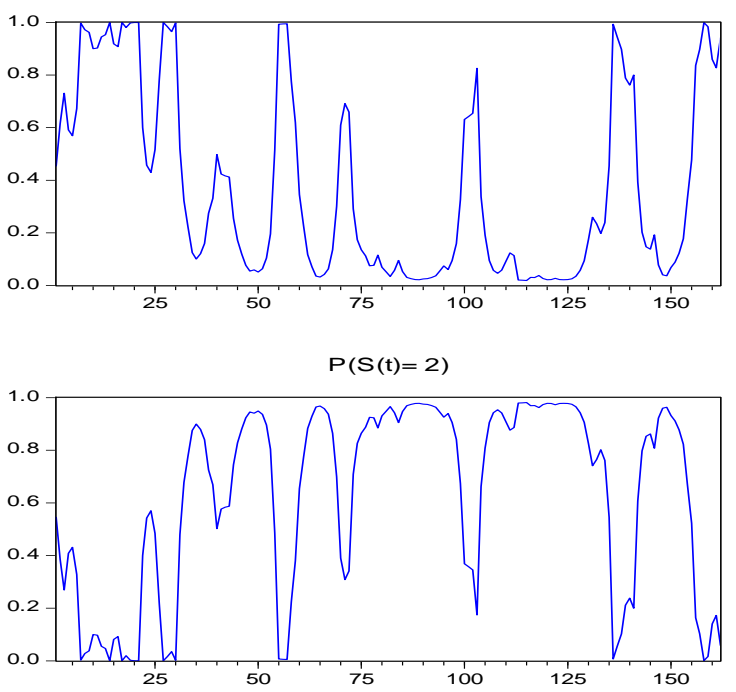

$\mathrm{KLCl}$
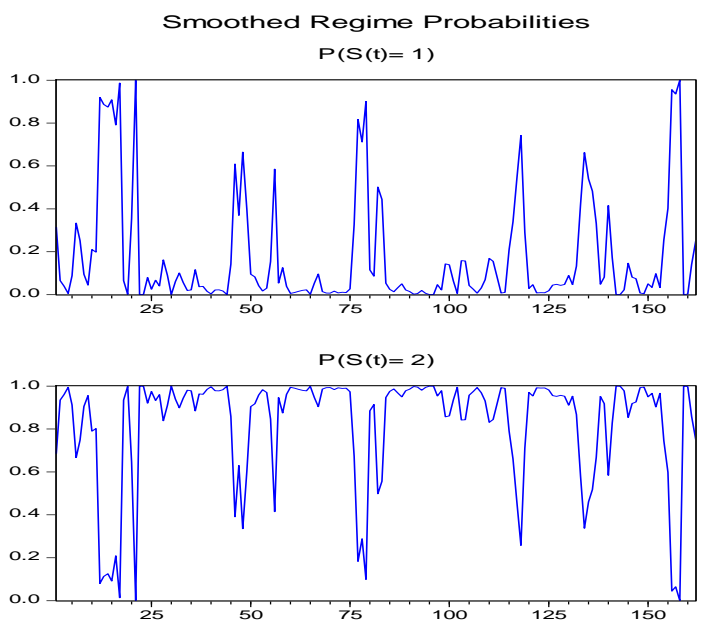

PSI
Smoothed Regime Probabilities $P(S(t)=1)$

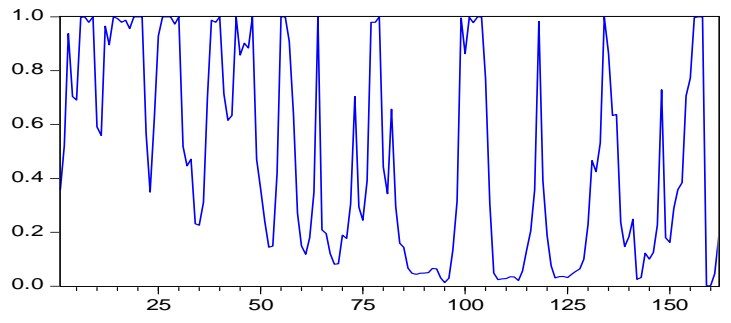

$P(S(t)=2)$

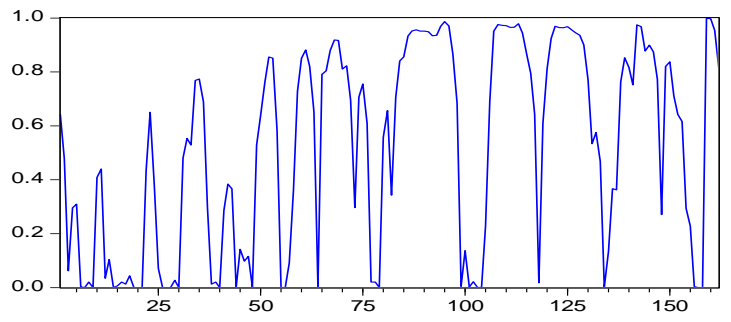

JSE

Smoothed Regime Probabilities $P(S(t)=1)$
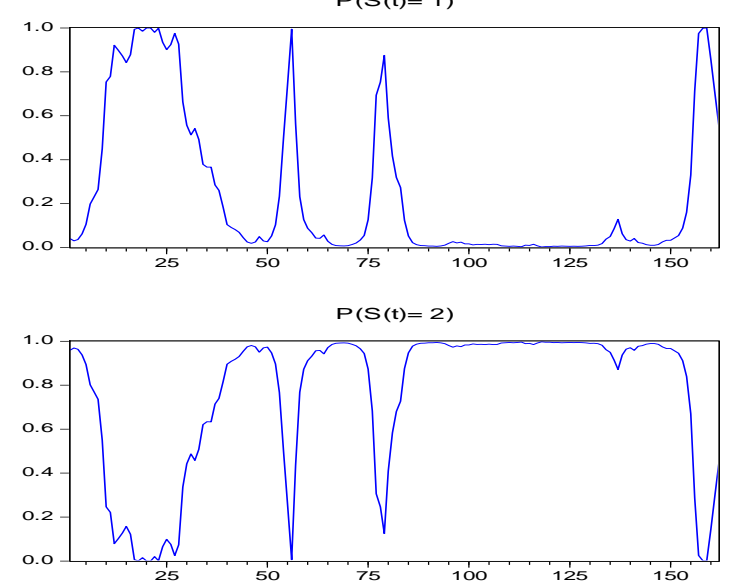

SET 
INTERNATIONAL JOURNAL OF ACADEMIC RESEARCH IN ACCOUNTING, FINANCE AND MANAGEMENT SCIENCES

Vol. 12 , No. 1, 2022, E-ISSN: 2225-8329 @ 2022 HRMARS

One-step Ahead Predicted Regime Probabilities $P(S(t)=1)$
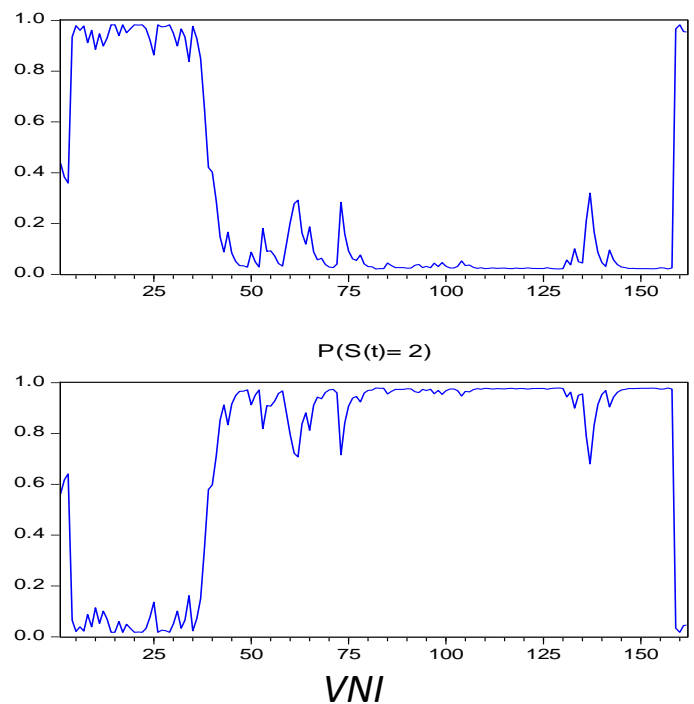